\title{
Can We Help Information Systems Students Improve Their Ethical Decision Making?
}

\author{
Theda Thomas and Mary Ahyick \\ Australian Catholic University, Melbourne, Australia
}

theda.thomas@acu.edu.au

\begin{abstract}
As the use of technology increases, the scope of computer-related ethical dilemmas continues to change. Information Systems graduates need to be prepared to work ethically in this everchanging environment. This exploratory research investigates if students who have undertaken an ethics subject differ in their ethical decision making from those who have not undertaken the subject. The questionnaire asked students to read ethical dilemmas focusing on software piracy and the theft of music. They were then asked to evaluate the person's actions, how important they felt the issue was, and how likely they were to follow the example of the person in the dilemma. They were also asked to rate different factors as to how they had influenced their decision making. The results for those who had undertaken an ethics unit were then compared with the results of those who had not. The paper concludes by making suggestions as to what the best method of helping students, not only develop their knowledge of ethical decision making and ethical issues, but also see the value of those and apply the decision-making techniques within their own lives.
\end{abstract}

Keywords: IT Ethics, Ethics Education, Cyberethics

\section{Introduction}

As the use of technology increases and technology advances, the scope of ethical dilemmas continues to change and the number of issues that require ethical decisions multiplies. Some of the major issues in Information Technology (IT) that have created much debate include privacy, security, hacking, intellectual property, copyright, government and employee monitoring, freedom of speech on the Internet, computer and internet crimes, and the tools used by perpetrators to commit them.

Information Systems graduates need to be prepared to work ethically in this ever-changing environment. The Australian Computer Society (ACS) promotes the "pursuit of excellence, rigor, integrity and honesty inherent in a truly professional approach" (Australian Computer Society [ACS], 2008). In order for a course to be accredited by the ACS, the university must show that it incorporates the learning of ethics and social values into the course. Spradling, Soh, and Ansorge

Material published as part of this publication, either on-line or in print, is copyrighted by the Informing Science Institute. Permission to make digital or paper copy of part or all of these works for personal or classroom use is granted without fee provided that the copies are not made or distributed for profit or commercial advantage AND that copies 1) bear this notice in full and 2) give the full citation on the first page. It is permissible to abstract these works so long as credit is given. To copy in all other cases or to republish or to post on a server or to redistribute to lists requires specific permission and payment of a fee. Contact Publisher@InformingScience.org to request redistribution permission.
(2008) report that social and profes-

sional standards (including ethics) have been included in computer science curriculum accreditation in the United States since 1987. Two outcomes required for the Accreditation of Computing Programs are related to ethics, namely: an understanding of professional, ethical, and social responsibilities; and an ability to analyze the impact of computing on individuals, organiza- 
tions and society, including ethical, legal, security, and global policy issues (Canosa \& Lucas, 2008).

"Cyberethics" is the term used to describe the discipline that analyses the moral, legal, and social issues surrounding the computing and internet technology areas. Cyberethics studies the impact of computing and internet technology on ethical issues and assesses the new laws and social policies that have been produced in response to technological advancements (Tavani, 2004). Other expressions that are also used to refer to ethical issues involving computing and Internet technologies are "information ethics," "information technology ethics," "information and communication technology (ICT) ethics," "global information ethics," and "Internet ethics" (Spinello \& Tavani, 2001).

The main purpose of the study was to determine whether the completion of an IT ethics subject at university has an effect on students' ethical decision making. Students consistently evaluated the subject positively, but was the subject making a difference? This paper describes the need to teach ethics to Information Systems (IS) students and explains how this was undertaken in the subject "Ethics and Informatics." It then describes the research undertaken to determine whether students who had undertaken the subject were more aware of ethical considerations and whether their own actions would be changed by their participation in the subject. A discussion of the results follows together with a further look at the literature to determine recommendations as to how the teaching of the subject might be changed to make the subject more relevant to students.

\section{Teaching Ethics to Information Systems Students}

\section{The Importance of Teaching IS Students about Ethical Issues}

The Information Technology industry is continuing to change and grow. Our society is becoming more and more reliant on information systems in all aspects of life, thus increasing the risk of negative impact due to the unethical use of information technology (Baase, 2003).

The ethical issues facing information professionals today are more challenging than ever before. Ethics are being put to new tests because of these evolving and emerging technologies. The fundamental changes in our society and the equity or inequity within it are also causing ethical beliefs to be challenged further (Buchanan \& Caftori, 2000).

Many of the ethical issues associated with computers and the internet are the old ethical problems presenting themselves in new media (Bork \& Caftori, 2000). Privacy has always been an issue, but now that databases have become more prevalent and data is easily accessible the issue of protecting people's privacy is more important. Another example is the issue of freedom of speech that has been made more complex with the use of the Internet. People are finding new ways to avoid copyright issues and perpetrate crimes.

Johnson (2007) makes the point that computing is a critical part of our society and that those who work in the field of computers are trusted by others who do not necessarily understand how computers work. This makes it important that those who practice in the field of computers act ethically and are worthy of the trust put in them.

Some universities offer ethics as a separate subject while others embed it into the various subjects of the course. As discussed by Califf and Goodwin (2008), having it as a separate subject may cause students to see ethics as a separate side issue that is disconnected from the rest of what they learn. They suggest that if a separate subject is used, it should be taught near the end of the course in order to relate it to the subjects that they have already learnt. The problem with integrating it into subjects across a program is that then ethics is not taught by subject experts and is often left out. 
Australian Catholic University's mission statement includes the statement that its "ideal graduates will be highly competent in their chosen fields, ethical in their behavior, with a developed critical habit of mind, an appreciation of the sacred in life and a commitment to serving the common good" (ACU, 2009). This mission has led to ethics being integrated into the teaching of most subjects of the Information Systems degree as well as in a stand-alone subject called "Ethics and Informatics" which was taught to second semester second years or third years.

\section{The Subject - Ethics and Informatics}

The subject "Ethics and Informatics" introduced the students to different ethical theories and techniques for making ethical decisions.

Topics covered in the course included a number of ethical theories (taught by a lecturer in philosophy in the first half of the subject). Some of the theories considered were Morality and Ethics, Utilitarianism, Kantian Ethics, Natural Law, Justice, Rights and Responsibilities. Also included were some of the more informal ethical decision-making methods like the Golden Rule or "Would you do this in front of your mother?" The examples used in this part of the course were not necessarily Business examples or Information Systems examples but did allow the students to consider wider world issues of importance.

This was followed by the teaching of specific issues in Cyberethics (taught by an IS lecturer during the second half of the subject). These topics included the digital divide, privacy and security, monitoring staff, hacking and cracking, intellectual property and copyright, free expression on the Internet.

When studying the digital divide, for example, the students looked at data from around the world and determined the extent of the issue and the implications for undeveloped nations of the world. They also used the 2006 census data from Australia related to computer and internet usage and compared usage for indigenous and non-indigenous people; different age groups, and city versus regional groups. The class then discussed the consequences of the divide, the implications for future generations and the responsibility of those who "have" to those who do not.

The students were asked to consider the Australian Computer Society Code of Ethics (ACS, 2009. The Code of Ethics is built around six values and ideals, which are then used to determine standards of conduct for the profession. These values and ideals are:

i. $\quad$ Priorities - placing the interests of the community above those of myself;

ii. Competence - working competently and diligently for both clients and employers;

iii. Honesty - in representative of my skills, knowledge, services and products;

iv. Social Implications - try to enhance the quality of life of those affected by my work;

v. Professional Development - enhance my own professional development and that of colleagues, employees and students; and

vi. Information Technology Profession - enhance the integrity of the profession and the respect that each member has for others.

Case studies reflecting ethical dilemmas in Information Systems were used to help the students understand how to make ethical decisions using the theories that they had studied, applying the Code of Ethical Conduct of the Australian Computer Society and their own moral values. The case studies were used to help students to develop their analytical and critical thinking skills while making them aware of the ethical and social concerns in computing (Pretorius \& Barnard, 2004). 
There were four assessments:

a) A mid-semester test based on the philosophical ethical theories

b) An essay on an Information Systems ethics topic, for example, the digital divide, privacy, ethical issues in the workplace, monitoring staff, hacking and cracking, intellectual property, copyright, free expression and the Internet. They had to use the ethical theories that they had learnt to argue for/against a particular point of view on the issue.

c) A choice between taking part in a debate and leading a discussion of an ethical dilemma. Criteria used for evaluating the discussion included their ability to:

- Lead a discussion (rather than make a presentation);

- Identify the stakeholders and present the dilemma taking the different stakeholder points of view into account;

- Integrate their knowledge of at least two ethical theories and the Code of Ethical Conduct of the ACS into their discussion; and

- Present a coherent, well substantiated argument of different points of view and then substantiate their own point of view in the conclusion.

d) Students were asked to keep a journal with their reflections on one of the ethical dilemmas presented by the other students each week.

The subject had received excellent student evaluations in the two years that it had been taught, but there was a question as to whether these methods were influencing the student's own decision making.

\section{Research Methods}

The research focused on two particular IS dilemmas - one involving copyright and the other intellectual property. These issues were chosen as they were ones that the students could relate to and ones that they might have to think about in real life.

This paper focuses on two research questions of the study:

Q1. Do the decisions made regarding copyright and intellectual property differ between

IT students who have completed an ethics subject and those that have not?

Q2. Do the factors that influence decision making regarding copyright and intellectual property differ between IT students who have completed an ethics unit and those that have not?

A questionnaire was administered to two groups for this study. The questionnaire can be found in the Appendix. The two groups were IS students who have completed an ethics subject at Australian Catholic University (34 students) and IS students who had not completed an ethics subject at university (40 students). The sample was limited to first and third year IT students, giving a combined total of 74 students.

The survey was designed so that all identities remained anonymous. The survey was adapted from a study conducted by Kreie and Cronan (2000) on "Making Ethical Decisions." The questionnaire comprises demographic questions, then a description of the dilemmas and an explanation of the questions that follow. The questionnaire then provides two dilemmas followed by questions on those dilemmas.

The questionnaire used two dilemmas, the first of which was adapted from (Spinello, 2003) and the second created by the author. The details will be described in the results section.

The participants were firstly asked to judge whether the decision made within each dilemma was acceptable or unacceptable. The next three questions used a seven point Likert Scale and asked 
the participants what the likelihood was, that, if placed in the same situation they would make the same decision $(1=$ highly improbable to $7=$ highly probable $)$. The participants were also asked to judge the importance of the issues and the degree the issue was of concern $(1=$ unimportant issue to $7=$ extremely important issue). These questions were used to test hypothesis one.

The Chi Square test was used to analyze the data collected with regard to the participant's responses about the acceptability or unacceptability of the main characters' decisions in the two dilemmas. The Mann-Whitney U test was used to analyze the data which uses the Likert Scales.

Students were also asked to comment on the factors that they felt influenced their decision making for each scenario. The influences that were questioned were societal, personal values, personal environment, university/professional environment, legal environment, and business environment. The students were given the descriptions and sample questions in Table 1, to explain what was meant by each influence. The Mann-Whitney U test was also used to analyze the data on the influences.

\begin{tabular}{|l|l|l|}
\hline \multicolumn{2}{|c|}{ Table 1: Possible influences on ethical decision making } \\
\hline Influential factors & Description & An example question \\
\hline societal environment & Societies values, our culture. & $\begin{array}{l}\text { What does society say } \\
\text { should be done? }\end{array}$ \\
\hline personal values & $\begin{array}{l}\text { Your personal values and ex- } \\
\text { perience. }\end{array}$ & What do I say? \\
\hline personal environment & $\begin{array}{l}\text { Family, significant others, peer } \\
\text { group. }\end{array}$ & $\begin{array}{l}\text { What does mom say? What } \\
\text { do my friends say? }\end{array}$ \\
\hline $\begin{array}{l}\text { university/professional } \\
\text { environment }\end{array}$ & $\begin{array}{l}\text { Codes of conduct*, univer- } \\
\text { sity/professional expectations. }\end{array}$ & $\begin{array}{l}\text { What does my univer- } \\
\text { sity/profession say? }\end{array}$ \\
\hline legal environment & $\begin{array}{l}\text { Law, legislation and legal is- } \\
\text { sues. }\end{array}$ & What does the law say? \\
\hline business environment & $\begin{array}{l}\text { Corporate goals, cost implica- } \\
\text { tions, job security. }\end{array}$ & $\begin{array}{l}\text { What does my company } \\
\text { say? Will it affect my job? }\end{array}$ \\
\hline
\end{tabular}

* Codes of conduct can be IT policies regarding behavior, codes of conduct, behavior standards, and codes of ethics, e.g., Australian Computer Society Code of Ethics

\section{Research Results}

\section{Students' Responses for Dilemma 1}

This dilemma depicts a teacher named Roger, who requires specific software for his mathematics laboratory in order to help struggling students at the school. He requests, from the principal, the funding to purchase the correct number of licenses required for the computers. The principal states that there is not enough money in the school's budget to purchase the software as it is too expensive. The principal also said that they already have a copy of the software and that if Roger really needs it, to load the software on to the computers that require it. The only way for Roger to have obtained the software was to breach copyright; Roger decided to load the software onto all the computers that need it. This dilemma was adapted from Spinello (2003). 
Table 2: Comparison of students' beliefs regarding acceptable behavior: Dilemma 1

\begin{tabular}{|c|c|c|c|c|c|c|c|c|c|}
\hline & \multirow[b]{2}{*}{$\begin{array}{l}\text { Studied an } \\
\text { Ethics } \\
\text { Subject }\end{array}$} & \multirow[b]{2}{*}{$\mathrm{N}$} & \multicolumn{2}{|c|}{ Acceptable } & \multicolumn{2}{|c|}{ Unacceptable } & \multicolumn{3}{|c|}{ Pearson Chi Square } \\
\hline & & & $\mathrm{N}$ & $\%$ & $\mathrm{~N}$ & $\%$ & Value & df & $\begin{array}{l}\text { Asymp. } \\
\text { Sig. (2- } \\
\text { sided) } \\
\text { (p) }\end{array}$ \\
\hline \multirow{3}{*}{$\begin{array}{l}\text { Roger's Deci- } \\
\text { sion }\end{array}$} & Yes & 34 & 15 & 44.1 & 19 & 55.9 & \multirow{3}{*}{0.884} & \multirow{3}{*}{1} & \multirow{3}{*}{0.347} \\
\hline & No & 40 & 20 & 50.0 & 20 & 50.0 & & & \\
\hline & Total & 74 & 35 & 47.3 & 39 & 52.7 & & & \\
\hline
\end{tabular}

As shown in Table 2, of the 40 students that had not completed an ethics subject, $50 \%$ believed that Roger's decision to copy the software onto the computer laboratory computers was acceptable. Of the 34 students that had completed an ethics subject, $44.1 \%$ of students believed that Roger's decision was acceptable. No significant difference was found when the Pearson Chi Square test was performed on Roger's decision ( $\mathrm{p}=0.347)$.

Table 3: Comparison of students' ethical decision making: Dilemma 1

\begin{tabular}{|c|c|c|c|c|c|c|c|c|}
\hline & $\begin{array}{l}\text { Studied an } \\
\text { Ethics Sub- } \\
\text { ject }\end{array}$ & $\mathrm{N}$ & $\begin{array}{l}\text { Mean } \\
(7 \\
\text { point } \\
\text { Likert } \\
\text { Scale) }\end{array}$ & SD & $\begin{array}{l}\text { Mann- } \\
\text { Whitney } \\
\text { U }\end{array}$ & $\begin{array}{l}\text { Wilcoxon } \\
\text { W }\end{array}$ & Z & $\begin{array}{l}\text { Asymp. } \\
\text { Sig. } \\
\text { (2- } \\
\text { tailed) } \\
\text { (p) }\end{array}$ \\
\hline \multirow{3}{*}{$\begin{array}{l}\text { Likelihood } \\
\text { that you } \\
\text { would do } \\
\text { the same }\end{array}$} & Yes & 34 & 4.06 & 2.145 & \multirow{3}{*}{612.500} & \multirow{3}{*}{1207.500} & \multirow{3}{*}{-0.192} & \multirow{3}{*}{0.847} \\
\hline & No & 37 & 4.14 & 1.766 & & & & \\
\hline & Total & 71 & 4.10 & 1.943 & & & & \\
\hline \multirow{3}{*}{$\begin{array}{l}\text { Issue Im- } \\
\text { portance }\end{array}$} & Yes & 34 & 4.91 & 1.929 & \multirow{3}{*}{434.500} & \multirow{3}{*}{1137.500} & \multirow{3}{*}{-2.275} & \multirow{3}{*}{0.023} \\
\hline & No & 37 & 3.97 & 1.787 & & & & \\
\hline & Total & 71 & 4.42 & 1.902 & & & & \\
\hline \multirow{3}{*}{$\begin{array}{l}\text { Degree } \\
\text { issue of } \\
\text { concern }\end{array}$} & Yes & 34 & 4.76 & 1.955 & \multirow{3}{*}{378.500} & \multirow{3}{*}{1044.500} & \multirow{3}{*}{-2.775} & \multirow{3}{*}{0.006} \\
\hline & No & 36 & 3.53 & 1.699 & & & & \\
\hline & Total & 70 & 4.13 & 1.918 & & & & \\
\hline
\end{tabular}

As can be seen from Table 3, the students who had completed an ethics subject thought the issue was more important and that the issue was of more concern than those that had not completed an ethics subject. Table 3 also shows the results from a Mann-Whitney U test. The first question showed no significant difference, confirming that the students and IT professionals were likely to do the same as Roger. The Mann-Whitney U test (Table 3) was also conducted on the importance of the issue ( $p=0.023)$ and to what degree the issue was of concern $(p=0.006)$. On these two issues, we do see a statistically different significance $(\mathrm{p}<0.05)$. This would suggest that the students were more aware of the issue but their own decision-making was not significantly affected by this awareness. There is evidence to suggest that the ethics unit made a statistically significant difference to students' understanding of the importance of the issue and their feeling that the issue was of concern. The disappointing thing is that although they found the issue to be of concern they were still likely to do the same as Roger and pirate the software.

In order to answer the second research question, the questionnaire then asked the students to respond to what they felt had influenced their decision. These results are provided in Table 4. As can be seen there were no statistically different results between the two groups regarding what influenced their decision making. 


\begin{tabular}{|c|c|c|c|c|c|c|c|c|}
\hline \multicolumn{9}{|c|}{$\begin{array}{c}\text { Table 4: Comparison of students' perceptions of the influences } \\
\text { on their decision making: Dilemma } 1\end{array}$} \\
\hline Degree of Influence & $\begin{array}{c}\text { Studied } \\
\text { an Eth- } \\
\text { ics } \\
\text { Unit } \\
\end{array}$ & $\mathrm{N}$ & Mean & SD & $\begin{array}{l}\text { Mann- } \\
\text { Whitney } \\
\text { U }\end{array}$ & $\begin{array}{l}\text { Wilcoxon } \\
\text { W }\end{array}$ & Z & $\begin{array}{l}\text { Asymp. } \\
\text { Sig. } \\
(2- \\
\text { tailed)(p) }\end{array}$ \\
\hline \multirow{3}{*}{ Societal Environment } & Yes & 34 & 2.79 & 0.880 & \multirow{3}{*}{562.500} & \multirow{3}{*}{1157.500} & \multirow{3}{*}{-1.351} & \multirow{3}{*}{0.177} \\
\hline & No & 40 & 3.08 & 1.023 & & & & \\
\hline & Total & 74 & 2.95 & 0.964 & & & & \\
\hline \multirow{3}{*}{ Personal values } & Yes & 34 & 3.62 & 1.015 & \multirow{3}{*}{636.500} & \multirow{3}{*}{1456.500} & \multirow{3}{*}{-0.503} & \multirow{3}{*}{0.615} \\
\hline & No & 40 & 3.55 & 0.846 & & & & \\
\hline & Total & 74 & 3.58 & 0.922 & & & & \\
\hline \multirow{3}{*}{ Personal Environment } & Yes & 34 & 2.94 & 1.179 & \multirow{3}{*}{648.000} & \multirow{3}{*}{1428.000} & \multirow{3}{*}{-0.171} & \multirow{3}{*}{0.864} \\
\hline & No & 39 & 2.85 & 1.065 & & & & \\
\hline & Total & 73 & 2.89 & 1.113 & & & & \\
\hline \multirow{3}{*}{$\begin{array}{l}\text { University/Professional } \\
\text { Environment }\end{array}$} & Yes & 34 & 3.62 & 1.129 & \multirow{3}{*}{643.500} & \multirow{3}{*}{1238.500} & \multirow{3}{*}{-.0412} & \multirow{3}{*}{0.680} \\
\hline & No & 40 & 3.75 & 1.032 & & & & \\
\hline & Total & 74 & 3.69 & 1.072 & & & & \\
\hline \multirow{3}{*}{ Legal Environment } & Yes & 34 & 3.74 & 1.310 & \multirow{3}{*}{668.000} & \multirow{3}{*}{1488.000} & \multirow{3}{*}{-0.135} & \multirow{3}{*}{0.892} \\
\hline & No & 40 & 3.72 & 1.219 & & & & \\
\hline & Total & 74 & 3.73 & 1.253 & & & & \\
\hline \multirow{3}{*}{ Business Environment } & Yes & 33 & 3.42 & 1.031 & \multirow{3}{*}{636.500} & \multirow{3}{*}{1197.500} & \multirow{3}{*}{-0.274} & \multirow{3}{*}{0.784} \\
\hline & No & 40 & 3.50 & 1.013 & & & & \\
\hline & Total & 73 & 3.47 & 1.015 & & & & \\
\hline
\end{tabular}

\section{Students' Responses to Dilemma 2}

The second dilemma in the questionnaire portrays Juliet, who received a new MP3 player for her birthday. Her colleagues all have MP3 players and download music using peer-to-peer file sharing networks. Juliet starts downloading free songs using one of the programs one of her workmates suggested, but it takes a long time to download one song. Her colleagues offer to copy the songs they have on their hard drives for her. Juliet decides to copy songs from her workmates to save time.

\begin{tabular}{|c|c|c|c|c|c|c|c|c|c|}
\hline \multicolumn{10}{|c|}{ Table 5: Comparison of students' beliefs regarding acceptable behavior: Dilemma 2} \\
\hline & \multirow[b]{2}{*}{$\begin{array}{l}\text { Studied an } \\
\text { Ethics Sub- } \\
\text { ject }\end{array}$} & \multirow[b]{2}{*}{$\mathrm{N}$} & \multicolumn{2}{|c|}{ Acceptable } & \multicolumn{2}{|c|}{ Unacceptable } & \multicolumn{3}{|c|}{ Pearson Chi Square } \\
\hline & & & $\mathrm{N}$ & $\%$ & $\mathrm{~N}$ & $\%$ & Value & $\mathrm{df}$ & $\begin{array}{l}\text { Asymp. Sig. } \\
\text { (2-sided) } \\
\text { (p) }\end{array}$ \\
\hline \multirow{3}{*}{$\begin{array}{l}\text { Juliet's } \\
\text { Decision }\end{array}$} & Yes & 34 & 24 & 70.6 & 10 & 29.4 & \multirow{3}{*}{0.884} & \multirow{3}{*}{1} & \multirow{3}{*}{0.347} \\
\hline & No & 40 & 32 & 80.0 & 8 & 20.0 & & & \\
\hline & Total & 74 & 56 & 75.7 & 18 & 24.3 & & & \\
\hline
\end{tabular}

As can be seen from Table 5, more students who had completed an ethics subject believed that Juliet's decision was unacceptable than those that had not. The majority of students who had completed an ethics subject also believed that Juliet's decision was acceptable. 
Eighty percent of the students who had not undertaken the ethics unit thought that it is acceptable compared to $70.6 \%$ of those who had taken the ethics subject. The results of the Chi Square test are shown in Table 5 and show that this difference was not found to be significant $(\mathrm{p}=0.347)$. The majority of students whether they had completed an ethics subject or not, believed that Juliet's decision was acceptable.

Table 6: Comparison of students' ethical decision making: Dilemma 2

\begin{tabular}{|c|c|c|c|c|c|c|c|c|}
\hline & $\begin{array}{l}\text { Studied } \\
\text { an } \\
\text { Ethics } \\
\text { Subject }\end{array}$ & $\mathrm{N}$ & Mean & $\mathrm{SD}$ & $\begin{array}{l}\text { Mann- } \\
\text { Whitney } \\
\text { U }\end{array}$ & $\begin{array}{l}\text { Wilcoxon } \\
\text { W }\end{array}$ & Z & $\begin{array}{l}\text { Asymp. } \\
\text { Sig. } \\
\text { (2-tailed) } \\
\text { (p) }\end{array}$ \\
\hline \multirow{3}{*}{$\begin{array}{l}\text { Likelihood that } \\
\text { you would do } \\
\text { the same }\end{array}$} & Yes & 34 & 2.97 & 2.195 & \multirow{3}{*}{635.000} & \multirow{3}{*}{1415.000} & \multirow{3}{*}{-0.326} & \multirow{3}{*}{0.744} \\
\hline & No & 39 & 2.90 & 2.210 & & & & \\
\hline & Total & 73 & 2.93 & 2.188 & & & & \\
\hline \multirow{3}{*}{$\begin{array}{l}\text { Issue Impor- } \\
\text { tance }\end{array}$} & Yes & 34 & 3.97 & 1.425 & \multirow{3}{*}{591.000} & \multirow{3}{*}{1257.000} & \multirow{3}{*}{-0.251} & \multirow{3}{*}{0.802} \\
\hline & No & 36 & 3.81 & 2.095 & & & & \\
\hline & Total & 70 & 3.89 & 1.790 & & & & \\
\hline \multirow{3}{*}{$\begin{array}{l}\text { Degree issue of } \\
\text { concern }\end{array}$} & Yes & 34 & 4.00 & 1.393 & \multirow{3}{*}{592.000} & \multirow{3}{*}{1333.000} & \multirow{3}{*}{-0.623} & \multirow{3}{*}{0.534} \\
\hline & No & 38 & 3.68 & 1.905 & & & & \\
\hline & Total & 72 & 3.83 & 1.678 & & & & \\
\hline
\end{tabular}

Although students who had completed an ethics subject were less likely to do the same as Juliet than students who had not completed an ethics subject, no significant differences were found as shown in Table 6 . The issue was marginally of more importance and concern to students who had completed an ethics subject.

As with the first dilemma, students who had undertaken an ethics unit did not report significant differences in their perceptions of what had influenced their decision despite having spent one semester studying ethics. This is shown in Table 7.

Table 7: Comparison of students' perceptions of the influences on their decision making: Dilemma 2

\begin{tabular}{|c|c|c|c|c|c|c|c|c|}
\hline Degree of Influence & $\begin{array}{l}\text { Studied } \\
\text { an Eth- } \\
\text { ics Unit }\end{array}$ & $\mathrm{N}$ & Mean & SD & $\begin{array}{c}\text { Mann- } \\
\text { Whitney } \\
\text { U }\end{array}$ & $\begin{array}{c}\text { Wilcoxon } \\
\text { W }\end{array}$ & $\mathrm{Z}$ & $\begin{array}{c}\text { Asymp. } \\
\text { Sig. } \\
(2- \\
\text { tailed)(p) }\end{array}$ \\
\hline \multirow{3}{*}{$\begin{array}{l}\text { Societal } \\
\text { Environment }\end{array}$} & Yes & 34 & 2.74 & 1.136 & \multirow{3}{*}{592.000} & \multirow{3}{*}{1187.000} & \multirow{3}{*}{-0.985} & \multirow{3}{*}{0.324} \\
\hline & No & 40 & 3.02 & 1.143 & & & & \\
\hline & Total & 74 & 2.89 & 1.142 & & & & \\
\hline \multirow{3}{*}{ Personal values } & Yes & 34 & 3.41 & 1.048 & \multirow{3}{*}{653.500} & \multirow{3}{*}{1248.500} & \multirow{3}{*}{-0.302} & \multirow{3}{*}{0.763} \\
\hline & No & 40 & 3.55 & 1.011 & & & & \\
\hline & Total & 74 & 3.49 & 1.024 & & & & \\
\hline \multirow{3}{*}{$\begin{array}{l}\text { Personal } \\
\text { Environment }\end{array}$} & Yes & 34 & 3.21 & 1.175 & \multirow{3}{*}{659.500} & \multirow{3}{*}{1479.500} & \multirow{3}{*}{-0.230} & \multirow{3}{*}{0.818} \\
\hline & No & 40 & 3.15 & 1.189 & & & & \\
\hline & Total & 74 & 3.18 & 1.175 & & & & \\
\hline
\end{tabular}




\begin{tabular}{|c|c|c|c|c|c|c|c|c|}
\hline \multicolumn{9}{|c|}{$\begin{array}{c}\text { Table 7: Comparison of students' perceptions of the influences on their decision making: } \\
\text { Dilemma } 2\end{array}$} \\
\hline Degree of Influence & $\begin{array}{l}\text { Studied } \\
\text { an Eth- } \\
\text { ics Unit }\end{array}$ & $\mathrm{N}$ & Mean & SD & $\begin{array}{c}\text { Mann- } \\
\text { Whitney } \\
\text { U }\end{array}$ & $\begin{array}{l}\text { Wilcoxon } \\
\text { W }\end{array}$ & Z & $\begin{array}{l}\text { Asymp. } \\
\text { Sig. } \\
(2- \\
\text { tailed)(p) }\end{array}$ \\
\hline \multirow{3}{*}{$\begin{array}{l}\text { University/Professional } \\
\text { Environment }\end{array}$} & Yes & 34 & 2.38 & 0.954 & \multirow{3}{*}{642.000} & \multirow{3}{*}{1462.000} & \multirow{3}{*}{-0.430} & \multirow{3}{*}{0.667} \\
\hline & No & 40 & 2.35 & 1.189 & & & & \\
\hline & Total & 74 & 2.36 & 1.080 & & & & \\
\hline \multirow{3}{*}{$\begin{array}{l}\text { Legal } \\
\text { Environment }\end{array}$} & Yes & 34 & 2.94 & 1.455 & \multirow{3}{*}{653.000} & \multirow{3}{*}{1473.000} & \multirow{3}{*}{-0.301} & \multirow{3}{*}{0.764} \\
\hline & No & 40 & 2.83 & 1.430 & & & & \\
\hline & Total & 74 & 2.88 & 1.433 & & & & \\
\hline \multirow{3}{*}{$\begin{array}{l}\text { Business } \\
\text { Environment }\end{array}$} & Yes & 32 & 2.66 & 1.310 & \multirow{3}{*}{615.000} & \multirow{3}{*}{1143.000} & \multirow{3}{*}{-0.291} & \multirow{3}{*}{0.771} \\
\hline & No & 40 & 2.75 & 1.354 & & & & \\
\hline & Total & 72 & 2.71 & 1.326 & & & & \\
\hline
\end{tabular}

\section{Discussion}

The results help us to answer the two research questions. The first research question was, "Do the decisions made regarding copyright and intellectual property differ between IT students who have completed an ethics subject and those that have not?" The results indicate that completing an ethics subject may have had some impact on students, by making them more aware of what was right and wrong and that things are not always black and white. It also makes them more aware that this is an important issue and one that is of concern. However, many of the students seemed to be aware of what was right and wrong without the need for completing an ethics subject. The ethics subject also did not seem to have any effect on the participants' own behavior. In both scenarios there was no significant impact on the whether the students would have followed in the footsteps of the person in the scenario.

The second research question was, "Do the factors that influence decision making regarding copyright and intellectual property differ between IT students who have completed an ethics unit and those that have not?" There was no indication that taking the ethics unit meant that the students felt differently about what had influenced their decision making.

Other studies (Al-Rafee \& Cronan, 2006 ; Kreie \& Cronan, 2000), have found that the importance of the issue affects the factors that influence people to make the decisions they make. In this study only two dilemmas were used focusing on copyright and intellectual property. Future research could include more scenarios spreading to wider topics such as privacy, Internet crimes, or the digital divide. This would help to determine if the context of the scenario affected the disappointing results found.

One of the interesting aspects of the students' responses was that although $75 \%$ of students thought that Juliet's decision was acceptable and only $47.3 \%$ thought that Roger's was acceptable, the responses from students regarding whether they would do the same as Juliet or Roger, were 2.18 for Judith's case and 4.10 for Roger's case on the 7 point Likert Scale. When questioned verbally after the study was completed, the students in the ethics class thought that they would have done the same as Roger in order to help the students in the school who needed the mathematics software. They took a Utilitarian point of view that this would bring the greatest good to the greatest number of people.

Current literature is now used to gain some insight into methods that might be used to improve the influence that the ethics subject has on students' behavior. 
The first issue identified with this particular offering of the subject was that the subject was offered in two parts - the first being taught by a philosophy lecturer and the second by an IT lecturer. Although the students were asked to apply their ethical theories from philosophy when considering the dilemmas used in their assessments, they had difficulty doing this.

The students need to be given a framework for making ethical decisions so that they learn how to apply the theory to the practice (McNamara, 2008). Many textbooks also contain frameworks that could be used. These frameworks could help students to link what they have learnt from a philosophical perspective to the world of computing. A recommendation for people teaching ethics and information systems would be that a greater focus be placed on the process of ethical decision making.

Sherman (2007) makes the point that the ethical dilemmas that we often use in IT ethics courses are not situations that the students typically have experienced. She says that, while the issues that we use are important for students as they enter the workforce, being able to relate some of the issues to their personal experience would make the course more interesting and relevant. This is supported by von Konsky, Ivins, and Gribble (2007), who conclude that it is important for case studies to be used that are relevant to students.

Most of the ethical case studies that were undertaken in class and through the assessment in the subject used for this research were not cases that the students typically would have experienced. The issues that they were asked to comment on (for the research) about the copying of music from their friends and pirating software were very likely ones that that they had encountered. Sherman (2007) undertook a study of the ethical issues that students face and found that theft (including theft of music and software), management misconduct, lying, cheating, and privacy issues were the four top scenario categories that were identified. In order to give students practice at applying the ethical frameworks to decision making, it would be good in the future to ensure that at least some of the scenarios that the students are asked to consider in class are ones that they can relate to their own experience.

One of the issues used in the questionnaire was around Roger pirating software so that his students would be able to have the mathematics program that they needed (as adapted from Spinello, 2003). It is important that the students learn that although there may be a clear and definite right and wrong to a problem, it is never that simple as there may be external influences which cause right and wrong to blur, as with Roger. What Roger did was clearly illegal but he did it because the students would not be able to get the help they need without it, which confuses the issue. Students need to learn to consider the issue from the point of view of different stakeholders. Califf and Goodwin (2005) have used the same scenario used in the first dilemma (Spinello, 2003) with students in a programming course and asked them to consider the issue from the point of view of the programmer of the software who would not be receiving any royalties.

Something else that should be focused on when teaching ethics in IT are the laws that surround the unethical use of computer technology and the severe penalties if caught breaching copyright or stealing intellectual property. Although people are aware that software and music piracy are illegal, many people believe that they will not be caught and penalized for small infractions, only the larger more professional groups will be punished as has been the case thus far (Al-Rafee \& Cronan, 2006).

\section{Conclusions}

For many years now the need to integrate the teaching of ethics and professional practice into Information Systems and Computer Science curricula has been acknowledged. This study explored whether the teaching of ethics as a separate unit had influenced the students awareness and concern about ethical issues. 
There are many limitations to this study, the main one being the size of the sample and the number of case studies upon which the results are based. For this reason the research can be seen as exploratory and has been used to determine whether the course we had been teaching in ethics was effective in helping students understand the importance of various issues as well as being effective in changing their behavior. Further research with students from a number of different universities would be needed to determine whether the results from this exploratory research can be extended to the general population of IS students. It would also be interesting to investigate different types of case studies - ones that the student may come across in their daily lives as well as hypothetical ones and determine if this makes a difference to students' decision making.

The research found that while students who had taken the ethics course were more aware of the issues and thought them important (at least in one of the cases); their behavior was not changed significantly.

There was also no difference in their perceptions of what influenced their decision making despite the fact that the students had undertaken an entire subject in ethics.

Suggestions were made as to how the course might be changed and further research would be needed to determine if these changes have helped the students apply the ethical principles to their own lives.

Despite these results, the authors still consider it to be important for Information Systems students to learn ethics. The study of ethics helps students to understand different points of view and allows them to consider other people and their needs. The study of ethical dilemmas helps students to consider their options in a safe environment and opens their minds to different possibilities and choices that they may need to make later in life. Who knows what influence that would have on them in later life?

\section{References}

ACU. (2009). Australian Catholic University Mission. Available from http://www.acu.edu.au/about acu/the university/philosophy values and mission/

Al-Rafee, S., \& Cronan, T. P. (2006). Digital piracy: Factors that influence attitude toward behaviour. Journal of Business Ethics, 63, 237-259.

Australian Computer Society. (2009). Australian computer society code of ethics. Retrieved October 24, 2009, from https://www.acs.org.au/index.cfm?action=show\&conID=200509022322219027

Baase, S. (2003). A gift of fire (2nd ed.). New Jersey: Pearson Education.

Bork, A., \& Caftori, N. (2000). Computers and major ethical problems in our society. The CPSR Newsletter, $18(2), 2$.

Buchanan, E., \& Caftori, N. (2000). Ethics in technology. The CPSR Newsletter, 18(2), 1.

Califf, M. E., \& Goodwin, M. (2005). Effective incorporation of ethics into courses that focus on programming. Proceedings of the 36th SIGCSE Technical Symposium on Computer Science Education, St. Louis, Missouri, USA, February 23-27, 347-351

Canosa, R. L., \& Lucas, J. M. (2008). Mock trials and role playing in computer ethics courses. Proceedings of SIGCSE, March 12-15, 2008, Portland, Oregan, 148-152.

Johnson, D. G. (2007). Computer professional ethics in theory and practice. Proceedings of the 29th International Conference on Software Engineering.

Kreie, J., \& Cronan, T. P. (2000). Making ethical decisions. Communications of the ACM, 43(12), 66-71.

McNamara, C. (2008). Complete guide to ethics management: An ethics toolkit for managers. Retrieved October 24, 2009, from http://www.managementhelp.org/ethics/ethxgde.htm 
Pretorius, L., \& Barnard, A. (2004). E-mail and misinformation: A South African case study. Proceedings of the 2004 Informing Science and IT Education Joint Conference, Rockhampton, Australia, 25-28 June, 2004, 123-142.

Sherman, C. A. (2007). Ethics: Making it real for information technology students. Proceedings of Consortium for Computing Sciences in Colleges, 22(3), 168-174.

Spinello, R. A. (2003). Case studies in information technology ethics (2nd ed.). Upper Saddle River, NJ: Prentice Hall.

Spinello, R. A., \& Tavani, H. T. (2001). Readings in cyberethics. Sudbury, MA: Jones and Bartlett.

Spradling, C. L., Soh, L-K, \& Ansorge, C. J. (2008). Ethics training and decision-making: Do computer science programs need help? Proceedings of SIGCSE'08, March 12-15, 2008, Portland, Oregon, USA, 153-157.

Tavani, H. T. (2004). Ethics and technology: Ethical issues in an age of information and communication technology. Hoboken, NJ: John Wiley \& Sons.

Von Konsky, B. R., Ivins, J., \& Gribble, S.J. (2007). Engaging undergraduates in discussions about ethics in computing. Ninth Australasian Computing Education Conference ACE2007, Ballarat, Victoria, Australia, January 2007. Conferences in Research in Practice in Information Technology, Vol. 66. Samuel Mann and Simon (Eds). 163-169.

\section{Appendix - Questionnaire}

(This questionnaire was adapted from a study conducted by Kreie and Cronan, 2000)

As this study is anonymous, please do not put your name on the questionnaire. Consent to take part in this study is implied by completing the questionnaire.

\section{DEMOGRAPHIC DATA}

Student:

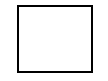

Professional:

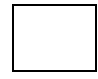

Years of University or TAFE Study (Students and Professionals):

Years of Experience (Professionals Only):

Australian Computer Society Member:

Yes

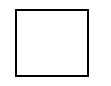

No

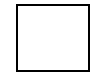

If yes, what level:

Have you studied an ethics unit at university or TAFE?

Yes

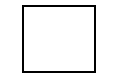

No 


\section{CASE STUDIES}

The following 2 cases describe certain situations and the behavior of people in those situations. You are asked to make some judgments about each scenario.

$<\quad$ Is the behavior of the person described in each scenario acceptable or unacceptable (ethical or unethical)?

$<\quad$ If you were the person in that situation, what is the probability you would have done the same thing?

$<\quad$ What is the importance of the ethical issue each scenario presents?

$<\quad$ What degree of influence do the following factors have on your assessment? (Factors are explained in the following table.)

Potential Influential Factors

\begin{tabular}{|l|l|l|}
\hline Influential factors & Description & An example question \\
\hline societal environment & Societies values, our culture. & $\begin{array}{l}\text { What does society say should } \\
\text { be done? }\end{array}$ \\
\hline personal values & Your personal values and experience. & What do I say? \\
\hline personal environment & Family, significant others, peer group. & $\begin{array}{l}\text { What does mom say? What } \\
\text { do my friends say? }\end{array}$ \\
\hline $\begin{array}{l}\text { university/professional envi- } \\
\text { ronment }\end{array}$ & $\begin{array}{l}\text { Codes of conduct*, univer- } \\
\text { sity/professional expectations. }\end{array}$ & $\begin{array}{l}\text { What does my univer- } \\
\text { sity/profession say? }\end{array}$ \\
\hline legal environment & Law, legislation and legal issues. & What does the law say? \\
\hline business environment & $\begin{array}{l}\text { Corporate goals, cost implications, job } \\
\text { security. }\end{array}$ & $\begin{array}{l}\text { What does my company say? } \\
\text { Will it affect my job? }\end{array}$ \\
\hline
\end{tabular}

* Codes of conduct can be IT policies regarding behavior, codes of conduct, behavior standards, and codes of ethics e.g. Australian Computer Society Code of Ethics

Please put a check mark for each factor for each scenario! 


\section{Case Study 1 (Spinello, 2003)}

Roger is a Math teacher and head of the Math department and has just received 22 used personal computers which have been donated to the Math department.

Currently the teachers must all put in extra time to help struggling students. The computers will help staff minimize the amount of time that is required to help these students if they can purchase a software package called MATH TUTOR. The software program will allow students to work at their own pace and allow teachers to spend more time preparing classes and providing innovative material to students. The school already owns one licensed copy of MATH TUTOR.

The following conversation takes place in the principal's office between Mary Lou, the principal and Roger:

"Well, then," responded Mary Lou, the principal, "why not just make copies for the ten machines. No one will ever know." Roger looked surprised and there was some hesitancy in his voice. "But that's stealing, isn't it? I know that we don't have a lot of money around here, but it's never right to copy software programs." Mary Lou was a bit taken aback by this response, but she was insistent. "Roger, I appreciate your concern, but let's be practical. We just can't afford to spend all that money for 10 copies of fairly expensive software. As I recall, these programs currently sell for \$695. That means almost \$7000!" "Well what about asking the software company to make a donation or give us a break on the price?" Roger asked. Mary Lou shook her head. "We tried that a year ago and the company refused. They have a firm policy of no giveaways."

Roger decides to copy the software.

a) Roger's decision was:

acceptable

unacceptable

b) If you were Roger, what is the probability that you would have loaded the software onto all computers that require it?

highly improbable _____________________________ probable

c) The issue behind the teacher's decision was an:

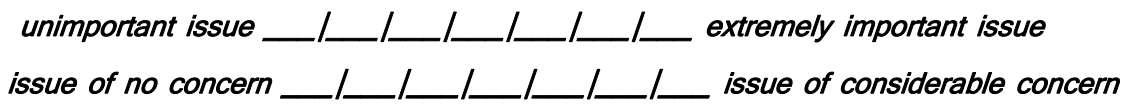

d) How much did each of the following factors influences your assessment of Roger's decision? Place a tick or cross in the appropriate box for each factor.

\begin{tabular}{|l|l|l|l|l|l|}
\hline Degree of influence: & None & Little & Moderate & Much & Great \\
\hline $\begin{array}{l}\text { Societal environment } \\
\text { (Societies values, our culture.) }\end{array}$ & & & & & \\
\hline $\begin{array}{l}\text { Personal values } \\
\text { (Your personal values and experience.) }\end{array}$ & & & & & \\
\hline $\begin{array}{l}\text { Personal environment } \\
\text { (Family, significant others, peer group.) }\end{array}$ & & & & & \\
\hline $\begin{array}{l}\text { University/Professional environment } \\
\text { (Codes of conduct*, professional ex- } \\
\text { pectations.) }\end{array}$ & & & & & \\
\hline $\begin{array}{l}\text { Legal environment } \\
\text { (Law, legislation and legal issues.) }\end{array}$ & & & & & \\
\hline $\begin{array}{l}\text { Business environment } \\
\text { (Corporate goals, cost implications, job } \\
\text { security.) }\end{array}$ & & & & & \\
\hline
\end{tabular}




\section{Case Study 2}

Juliet received a brand new top of the range, MP3 player for her birthday. This means that she'll have something to occupy the long trips to and from work. Her colleagues all have MP3 player's and download music using peer-to-peer file sharing software. This means that they share songs with other people using the same software for no cost.

Juliet starts downloading free songs using one of the programs one of her workmates suggested but it takes a long time to download one song. The program allows to her to share songs she has download with others and for her to download songs other people have downloaded off their computer hard drive. Her colleagues offer to copy the songs they have for her.

Juliet decides to copy songs from her workmates to save time.

a) Juliet's decision was:

\section{acceptable}

unacceptable

b) If you were Juliet, what is the probability that you would have made the same decision?

highly improbable _______________________________ probable

c) The issue behind Juliet's decision was an:

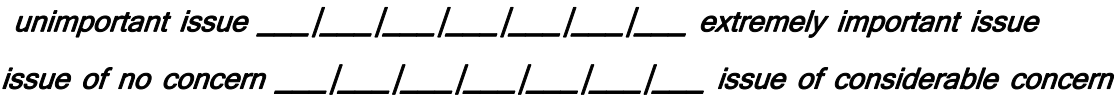

d) How much did each of the following factors influences your assessment of Juliet's decision? Place a tick or cross in the appropriate box for each factor.

\begin{tabular}{|l|l|l|l|l|l|}
\hline Degree of influence: & None & Little & Moderate & Much & Great \\
\hline $\begin{array}{l}\text { Societal environment } \\
\text { (Societies values, our culture.) }\end{array}$ & & & & & \\
\hline $\begin{array}{l}\text { Personal values } \\
\text { (Your personal values and experi- } \\
\text { ence.) }\end{array}$ & & & & & \\
\hline $\begin{array}{l}\text { Personal environment } \\
\text { (Family, significant others, peer } \\
\text { group.) }\end{array}$ & & & & & \\
\hline $\begin{array}{l}\text { University/Professional environment } \\
\text { (Codes of conduct*, professional } \\
\text { expectations.) }\end{array}$ & & & & & \\
\hline $\begin{array}{l}\text { Legal environment } \\
\text { (Law, legislation and legal issues.) }\end{array}$ & & & & & \\
\hline $\begin{array}{l}\text { Business environment } \\
\text { (Corporate goals, cost implications, } \\
\text { job security.) }\end{array}$ & & & & & \\
\hline
\end{tabular}




\section{Biographies}

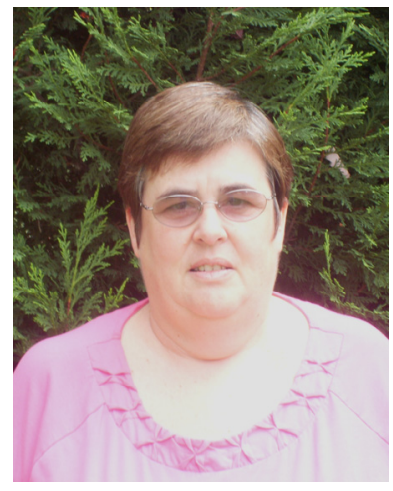

Theda Thomas has been teaching Information Systems in Higher Education in South Africa and Australia for more than 20 years. She is currently the Associate Dean (Learning and Teaching) for the Faculty of Arts and Sciences at the Australian Catholic University. Her research is mainly into the development of the non-technical skills needed by IS students. These include critical thinking, communication skills and ethical reasoning skills.

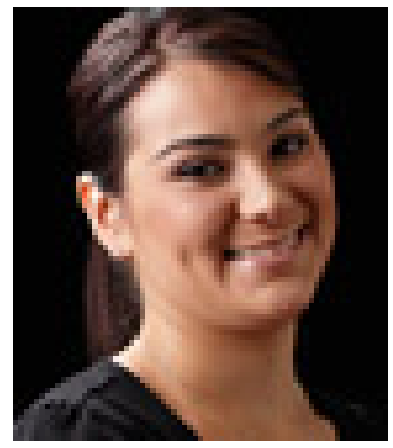

Mary Ahyick was a student at the Australian Catholic University and is currently working in the Information Technology department of Mars Pty Ltd. Mary Ahyick was a student at Australian Catholic University where she undertook a Bachelor of Information Systems with Honours. She is currently working for Mars Information Services in Datawarehousing. 